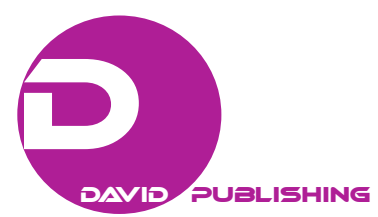

\title{
Conceptualising Strategy-Making Through a Strategic Architecture Perspective
}

\author{
Marius Ungerer \\ University of Stellenbosch Business School, Bellville, South Africa
}

\begin{abstract}
The key argument of this conceptual paper is that the roots of a viable future for an organisation are found in a robust strategic architecture perspective. The theoretical baselines for the concepts associated with this paper are linked to a variety of strategy theories. These include, but are not restricted to, institutional theory, strategic thinking relating to the positioning-based view (PBV) and resource-based view (RBV) respectively, entrepreneurial thinking, and innovation thinking. Strategy can be described as the collective, emerging pattern — based on strategic choices - an organisation consciously exhibits and executes over time to ensure its sustainable endurance by differentiating itself in unique ways to create and add value for stakeholders. Strategy is about explaining how an organisation wants to move forward and how it wants to advance the interests of stakeholders. A strategic landscape is the broad external and internal context of an organisation. An important part of strategy and the strategic landscape it operates in is how organisations define or "construct" their own "topography" or strategic architecture. A strategic architecture presents an organisation's core logic for creating sustainable value, and therefore, forms the foundation of an organisation's competitive potential in a specific context. This paper presents descriptions of the seven key buildings blocks that constitute a strategic architecture perspective for an organisation with an indication of strategy tools and frameworks that can be used to illuminate strategic possibilities, choices, and challenges to assist ongoing strategising praxis. The key features and assumptions associated with a strategic architecture perspective are discussed. A strategic architecture perspective assists leaders to work through the strategic complexity to arrive at simplicity in the form of clarity on external and internal strategic leverages, strategic aspirations, core strategic choices, plausible multiple scenarios, focused strategic goals, and success measurements to guide strategy execution and ongoing strategy renewal and innovations for proactive strategic decision-making through various dialogues with key stakeholders.
\end{abstract}

Keywords: business model, stakeholders, strategic architecture, strategy, strategising

\section{Introduction}

You cannot be strategic about the past. Whoever heard of anyone making plans for yesterday, or thinking deeply about the options for action for last month? It is in the very nature of things that we plan for tomorrow and think about what we will do at some point in the future. The reason we do this is quite clear: We have options. As we cannot predict with 100 per cent accuracy what will happen in the future, we must exercise our

Marius Ungerer, DCom, MBA, professor, Strategic Management, University of Stellenbosch Business School, Bellville, South Africa.

Correspondence concerning this article should be addressed to Marius Ungerer, University of Stellenbosch Business School, Bellville Park Campus, P. O. Box 610, Bellville 7535, South Africa. 
choices and make decisions, often under conditions of great uncertainty. Well, maybe we do not have to decide; we could always just let the future happen by taking our chances and letting the chips fall where they may. People may argue that the future will happen anyway, regardless of our plans. Of course, they are right-the future often happens despite our plans. But had we not planned, might we not end up further away from what we had hoped for? (Ungerer, Pretorius, \& Herholdt, 2011, p. xi)

Whichever way you look at it, human beings are concerned about the future and spend a great deal of time thinking about it. The late Victor Frankl (2006) spent 1944 and 1945 in World War II work camps. Daily, he experienced a reality where death seemed more worthwhile than life; indeed, it seemed like the only rational choice, yet people (including himself) survived. The only answer Frankl could find for this phenomenon was that they had something to live for something that gave enough meaning to their suffering, motivating them to continue living. Small wonder, then, that his definition of an optimally functioning individual is characterised by a healthy future directedness. This applies to all living systems, including organisations.

Often, we do more than just wish things would happen in a certain way: We make plans to influence events, to nudge things in the direction of a preferred future state - one where we have a greater measure of control over what happens to us. Organisational strategy development and execution (or strategising) is a continuous process of thinking and learning through various dialogues, where viable futures are uncovered, and sustainable strategies are developed using different strategy tools, processes, and approaches. As will be argued in this paper, the roots of a viable future are found in a robust strategic architecture.

\section{Background}

In a post-modern context, it is accepted that no single strategy tool or model will lead to a sustainable competitive advantage - there are no recipes (Rosenzweig, 2007; Christensen \& Raynor, 2003). The emphasis is, therefore, increasingly moving to the development of dynamic strategy processes (Oosthuizen, 2005, p. 69), where eclectic blends of models and techniques are brought together to meet the needs of a particular organisation, in a particular environment, at a particular time.

In the analysis of strategising processes in organisations, two primary approaches have been identified, namely a rational planned approach and an emergent process approach (Mintzberg, Ahlstrand, \& Lampel, 2009). The rational planned approach refers to the belief (or mind-set) that the future can be determined (more or less) by our intentions and plans, while the emergent perspective holds the view that the business world is so volatile and unpredictable that a business can only capitalise on opportunities as they present themselves in the short term. The rational strategy design process develops a strategy pattern beforehand and in emergent strategy practices a strategy pattern only becomes visible afterwards. Research confirms that most organisations combine these two approaches (Grant \& Jordan, 2015; Meissner, 2014; Titus, Covin, \& Slevin, 2011).

The impact of strategising practices on key organisational aspects, such as profitability and growth has been reviewed extensively (Andersen, 2000; Falshaw, Glaister, \& Tatoglue, 2006; Hakimpoor, 2014; Pearce, Freeman, \& Robinson, 1987) and confirms a general link, but many studies also report no relationship. Apart from methodological challenges, Rumelt (2011, as cited in Lovallo \& Medona, 2007) shed some light on the core issue by stating that being in the right industry is important, but being superior at what you do matters much more. Leaders of organisations need to "show the way" (Spears, 2010) by creating hope for the future and chiselling out a possible path towards it. Managers from around the world still find it useful and helpful to 
strategise (Stalk, 2004), as further confirmed in a 2015 survey (Rigby \& Bilodea, 2015) that shows strategy planning remains one of the most used business tools across the world.

The theoretical baselines for the concepts associated with this paper are linked to a variety of strategy theories. These include, but are not restricted to, institutional theory, strategic thinking relating to the positioning-based view (PBV) and resource-based view (RBV) respectively, entrepreneurial thinking, and innovation thinking.

Institutional theory is based on the intent to create a more strategic fit between an organisation and its external environment for achieving high performance results (Peng, 2000, p. 290). PBV refers to positioning an organisation in an industry in a way that enables it to achieve competitive advantage (Porter, 1998). Within this strategic positioning paradigm, strategy is about the creation of a unique and valuable position, involving a different set of activities (Porter, 1996, p. 10). The RBV represents an approach where the strategic resources and capabilities of an organisation are leveraged for comparative advantage or where these resources are utilised by the firm to achieve sustainable competitive advantage (Barney, 1991; Grant, 1991; Teece, Pisano, \& Shuen, 1997; Wernerfelt, 1984). Entrepreneurial theory supports working in an ever changing and dynamic business environment (Covin, 1991) and executing entrepreneurial strategy approaches (Alvarez \& Barney, 2007; Lynch, 2009) to spot and reap the benefits of new business opportunities. Both corporate entrepreneurship (Barringer \& Bluedorn, 1999) and corporate intrapreneurship (Pinchot, 1984) views are used, depending on the context of the organisation. Innovation-driven theories are reflected in diverse perspectives, such as disruptive and radical innovation (Büschgens, Bausch, \& Balkin, 2013; Christensen \& Overdorf, 2000; Hamel, 1996), incremental innovation (Koberg, Detienne, \& Heppard, 2003), business model creation and reinvention (Johnson, Christensen, \& Kagermann, 2008), and the Blue Ocean strategy approach (Kim \& Mauborgne, 2004).

It follows that the term "strategy" has multiple meanings and it will be explored after aspects related to theory-building are covered.

\section{Theory-Builing}

The development of a conceptual model is part of theory-building (Dubin, 1976) which represents a process of modelling real-world phenomena (Torraco, 1997). Theory means "an ordered set of assertions about a generic behaviour or structure assumed to hold throughout a significant broad range of specific instances" (Sutherland, 175, p. 9). In this paper, the intent is to conceptualise strategy-making through the lens of a strategic architecture perspective.

Conceptual models need to state the theoretical basis, define key constructs and the relationships among elements, and state key propositions that are logically consistent with the model (Kerssens-van Drongelen, 2001; Dubin, 1976; Weich, 1989; Whetton 1989). There are no generic templates that can be used to produce a required model (Torraco, 1997). Theory building starts with a practical problem or existing theory which is used to construct a new concept (Torraco, 1997).

In this paper, the main research question was: What are the main building blocks of an integrated view on the strategic architecture of an organisation? Sub-research questions were: How can strategy-making be depicted as a dynamic iterative process consisting of multiple constructs and practices? What are the key assertions associated with a strategic architecture perspective? 


\section{Strategy-Making}

A key question to address is: What is strategy and how is it created? Mintzberg (1987, p. 12) reminded us of the complexities associated with strategy:

Strategy is not just a notion of how to deal with an enemy or a set of competitors or a market, it draws us into some of the most fundamental issues about organisations as instruments for collective perception and action.

The strategy-making process consists of capturing learnings and insights through multiple analyses using a variety of sources and then synthesising these learnings into a position indicating the direction that the business should pursue (Mintzberg, 1994a; Rumelt, 2011). There is consensus (Mintzberg et al., 2009, pp. 16-17; Montgomery, 2012) that strategy is a multi-dimensional concept with key ingredients, such as a concern for both the internal and external environment. Its substance is complex and affects the overall welfare of an organisation; it involves both process and content aspects and is not purely deliberate; it exists on different levels and involves a variety of thought processes.

Strategy is not an end product, but rather a construct with a clear future intent that is continuously moulded and shaped on a journey with many feedback mechanisms, e.g., customer take-up and feedback; practical application experiences; and insights from strategy collaborators (Chia \& Holt, 2011; Hamel, 1996; Rumelt, 2011). Strategy formulation and execution have no end-line, but have many humble beginnings and rebuilds, based on the inspiration, foresight, and future aspirations of people relating with one another in a particular context. This means that strategy is a pattern of behaviour in a stream of actions that have consequences for the survival of the organisation in its competitive environment. This pattern emerges in the day-to-day activities of the organisation (De Wit \& Meyer, 2014; Grant, 2016; Mintzberg, 1987).

Strategy can therefore be described as

The collective, emerging pattern - based on strategic choices - an organisation consciously exhibits and executes over time to ensure its sustainable endurance by differentiating itself in unique ways to create and add value for stakeholders. Strategy is about explaining how an organisation wants to move forward and how it wants to advance the interests of stakeholders. (M. Ungerer, G. Ungerer, \& Herholdt, 2016b, p. 21)

This perspective on strategy recognises that it is static neither in process nor content (Drucker, 1986; Mintzberg, 1994b) and represents a system of value creation with mutually reinforcing parts (Magretta, 2012; Montgomery, 2012). Therefore, strategy making represents a dynamic future-oriented process that delivers organisational thinking, convictions, and artefacts as a result of ongoing strategic decision-making to enhance the unique strategic position(s) and differentiation features of the organisation, serving the needs and aspirations of multiple stakeholders (De Wit \& Meyer, 2014; Montgomery, 2012; Porter, 1996; Porter \& Kramer, 2011).

An effective strategy reflects a compelling reason for the existence of the organisation, explains strategic choices and differentiating positions that are difficult to imitate, gives clarity on activity system(s) for value creation, implements appropriate metrics to monitor progress, and makes stakeholder sensitivity a lived reality (Magretta, 2012; Montgomery, 2012; Porter, 1996).

\section{Strategic Architecture: Landscape}

A strategic landscape is the broad external and internal context of an organisation. The strategic landscape of a firm can be shaped by strategic actors, but the nature of the landscape also influences the strategic options 
and choices of players in the landscape. Landscaping activities by strategic actors vary and can, for example, include the development of new markets and influencing legislation to ensure freedom of access to information for stakeholders (M. Ungerer et al., 2016b).

An important part of strategy and the strategic landscape it operates in is how organisations define or "construct" their own "topography" or strategic architecture (Ungerer et al., 2011). Hamel and Prahalad (1990, p. 13) described a strategic architecture as the "road map of the future that identifies which core competencies to build". They introduce the concept of a strategic architecture as a broad intent of where and how an organisation wants to define itself in a strategic landscape. Kiernan (1993, p. 7) added another view, stating that a strategic architecture represents "that invisible intellectual, philosophical, and even normative 'DNA' which programs and lends coherence to virtually all important business decisions, whether they be strategic or operational".

Building on the above two views, a strategic architecture can be seen as an organisation's core logic for creating sustainable value, and therefore, forms the foundation of an organisation's competitive potential (Ungerer et al., 2011). It describes the context and the terrain that an organisation intentionally defines or constructs to achieve a desired end. It also influences the current competitive behaviour of the enterprise and may, therefore, explain why an organisation seems not to be competitive in current terms. The departure point is that competitive behaviour and potential can be altered and influenced when an organisation redefines its strategic architecture. A strategic architecture view of an organisation creates a platform to enable strategic choices by hardwiring it into the organisation. It underlies the success or failure of any strategy; therefore, it should be richly and concisely constructed and designed (M. Ungerer et al., 2016b). The strategic architecture of a firm is not equal to its business model (see detail on the business model as part of strategy formulation). The strategic architecture view of a firm is a more extensive and comprehensive strategic description. One of the components of this description represents the business model of a firm, which is therefore a subset of the strategic architecture (M. Ungerer et al., 2016b).

Hamel and Prahalad (1989) indicated that organisations should create their own internal competitive environments, rather than adapting existing ones. They found that highly successful organisations are differentiated from the rest because they creatively innovate around, and leverage off, their core competencies or capabilities. It seems as if such organisations are less obsessed with their competition and rather more concerned with reinventing themselves. This is in contrast to organisations that attempt to fit or adapt to their environments, often by following their competition. This paper supports the premise that competitiveness is internally generated and that an organisation must construct or reconstruct its fundamental underlying strategic architecture in order to be competitive.

A strategic architecture view of an organisation enables leadership to "confront the brutal facts and to act on the implications" (Collins, 2001, p. 89). The main building blocks of a strategic architecture perspective of an organisation are reflected in Figure 1.

The elements of the strategic architecture of an organisation consist of the following key strategic aspects:

Building Block 1: Strategic leadership as a key capacity for giving life, meaning and ongoing momentum to the strategy and strategising activities of an organisation, within ethical boundaries.

Building Block 2: The analysis and synthesis of both external and internal factors that can influence the strategic landscape and context of an organisation.

Building Block 3: Strategy formulation and development practices as reflected in core strategic choices to 
inform business model choices.

Building Block 4: The use of multiple futures perspectives based on scenarios to inform strategic decisions.

Building Block 5: The enablement of strategy execution through strategy mobilisation, strategy translation and strategy monitoring practices.

Building Block 6: The use of strategy renewal and innovation practices to bolster the competitiveness and sustainability of an organisation.

Building Block 7: Entrepreneurial leadership and strategy practices to foster both entrepreneurship and intrapreneurship.

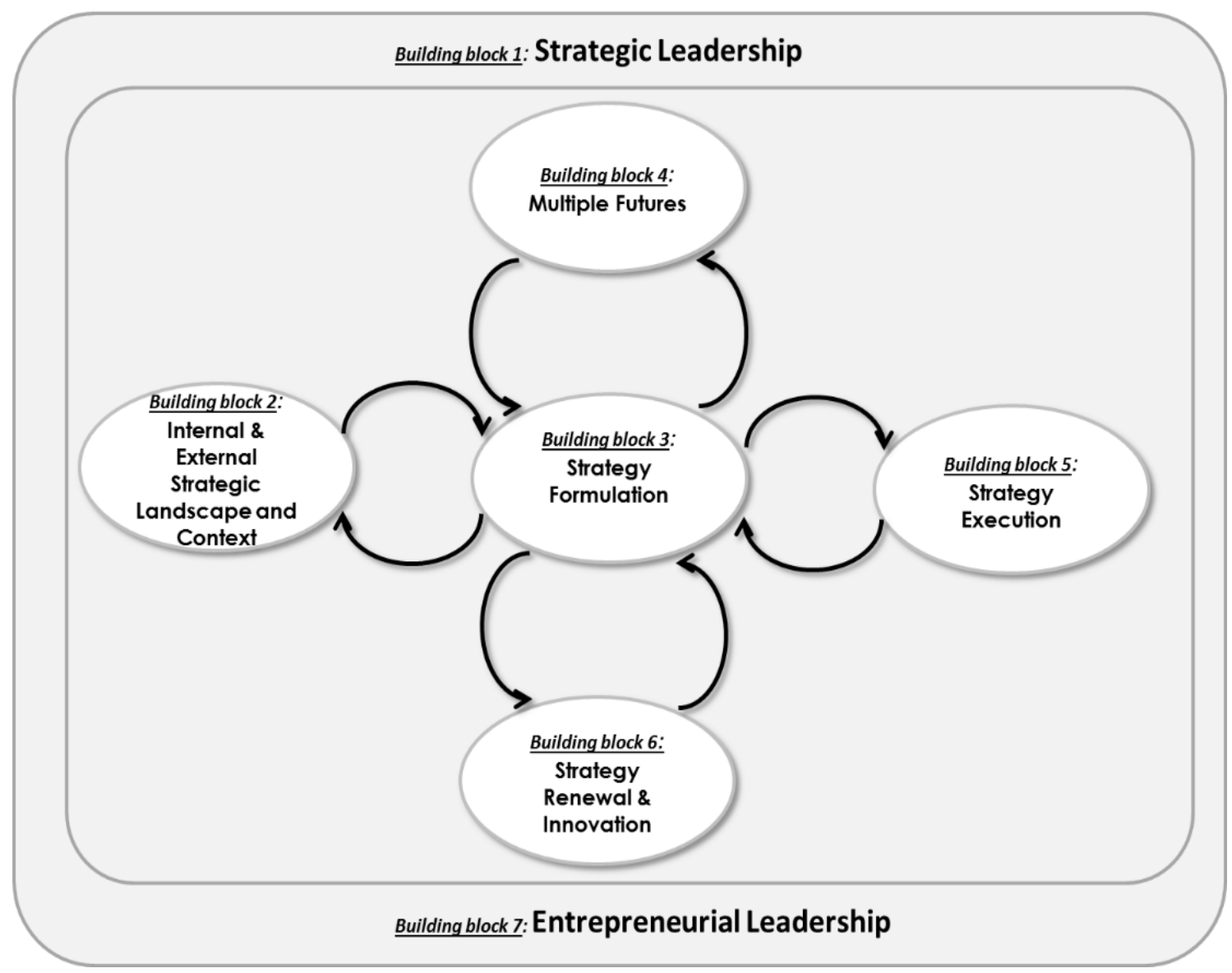

Figure 1. Inter-relatedness of the building blocks of strategic architecture (Author's own).

The seven building blocks of the strategic architecture of a firm are all inter-related, as shown in Figure 1. From a systemic point of view, the strategic architecture of a firm contains the key elements in a strategy system, but the system can only flourish if all the parts are connected in a virtuous way. The virtuous cycle of strategic thinking to unlock the potential of a strategic architecture perspective is reflected in Figure 2.

In the next section, a short description of the seven key buildings blocks that constitute a strategic architecture for an organisation is provided with an indication of strategy tools and frameworks that can be used to illuminate strategic possibilities, choices, and challenges to assist ongoing strategising praxis. 


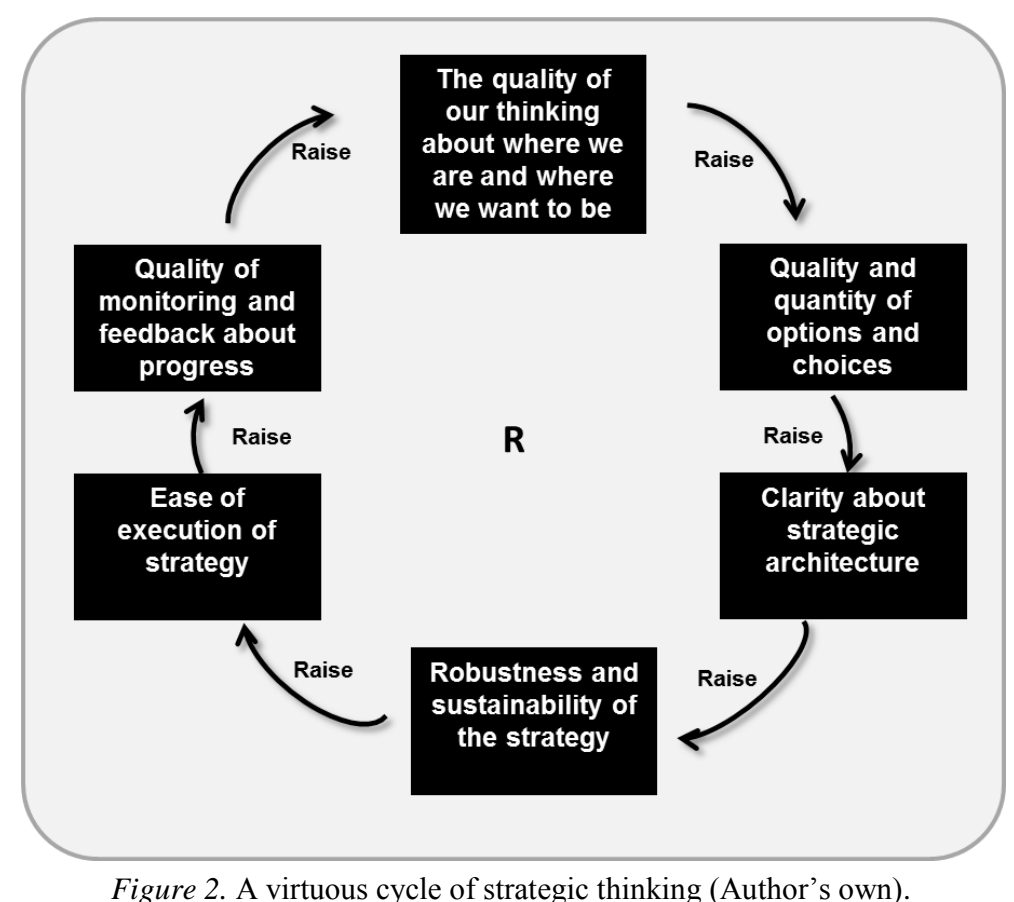

\section{Core Elements of a Strategic Architecture View}

\section{Building Block 1: Virtuous Strategic Leadership}

This paper supports the view of Phil Rosenzweig (2007, p. 156) that leadership and culture "are perhaps better understood as attributions based on performance rather than causes of performance". Strategic success is not based on a single cause but is the result of a number of variables interacting in a virtuous way. Rumelt (2011, p. 5) reminded us that "strategy cannot be a useful concept if it is a synonym for success". Research (Kotter, 2014; Rosenzweig, 2007) confirmed that strategy decision-makers should focus on developing their individual and collective capability to: (1) choose the winners from amongst the many available strategic options, and (2) consistently execute these strategic choices in an excellent way. Jim Collins (2001, p. 11) supported this view when he says: "Greatness is not a matter of circumstances. Greatness, it turns out, is largely a matter of conscious choice". Strategic leadership is a necessary-but not sufficient—condition for organisational success in the long run, given the complex nature of the concept strategy as already described.

Leadership is viewed from a post-heroic (Badaracco, 2001) perspective and as an organisational capacity that should be spread wide and deep in organisations; it can never be the exclusive task of a few executives at the "top" of the organisation. This implies a distributed leadership capacity as a crucial part of managing in the twenty-first century (Bolden, 2011), where leadership is conceived of as a collective social process emerging through the interactions of multiple actors (Uhl-Bien, 2006). Responsible leadership practices as virtuous leadership (Cameron, 2011) are advocated to foster sound moral decision-making. This theory emphasises the importance of leadership modelling by showing the way or setting a positive example (Ungerer, 2016). The argument is that "ethical virtuosity is not something for the puritans" (Rego, Cunha, \& Clegg, 2012, p. 19), but an empowering way of leading yourself and others in a world that responds to moral guidance and exemplary role models. The near-universal admiration for our President Mandela and the near-universal condemnation of President Trump of the USA are examples. 
Virtuous leadership practices can be stimulated through reflective exercises based on universal virtues (Peterson \& Seligman, 2004; Ungerer, Herholdt, \& Le Roux, 2013) and creating self-insights by exposing leaders to the 18-factor behaviour-based Virtuous Leadership Questionnaire (Wang \& Hackett, 2015).

\section{Building Block 2: External Environment Context Analysis and Internal Organisation Analysis}

Using the external environment as the reference point for a strategic analysis is based on the traditions and assumptions associated with the industrial organisation (I/O) model (Galbreath \& Galvin, 2008; Volberda et al., 2011) which states, inter alia, that the external environment of an organisation represents the major factors that will influence current and future strategic decisions and actions. This implies that the strategies that are formulated and implemented for an organisation to generate above-average returns are circumscribed by the characteristics of, and conditions present in, the external environment. Data-driven and facts-based strategic decision-making is a key departure point for successful strategy analysis and synthesis. Eisenhardt (1989) indicated that fast decision-makers use more, not less, information and that they develop more, not fewer, alternatives. This emphasises the need for the availability of a variety of data sources and options.

Global and macro trend enquiries, industry investigations, competitor evaluations and customer studies form the basis of an external analysis and each will be briefly described.

The following frameworks and tools can be used to capture global and macro trends, external opportunities and external threats: Sustainable Development Goals (SDGs) (UN, 2015a); UN Global Compact (UN, 2015b); analysis of global risks (WEF, 2018); analysis of national strategic priorities of a country to identify national development priorities (NDP, 2012); analysis of the impact of macro-environment forces using a STEEP approach (M. Ungerer, G. Ungerer, \& Herholdt, 2016a); a stakeholder analysis (Mitchell, Agle, $\&$ Wood, 1997), and a sustainable value analysis (Hart \& Milstein, 2003).

The focus of an industry analysis is to extract industry-related information first and then interpret the industry trends for future foresights about the industry developments and implications for a specific organisation. A good strategy analysis should cover and be concerned with both the structural evolution of an industry and with the firm's own unique positioning and future competitiveness within that industry (Porter, 2008). Frameworks that are relevant here include an industry-dominant economic features analysis (Thompson, Strickland, \& Gamble, 2010); industry profitability, profit pool, and market share analysis (Ungerer et al., 2016a); industry competitive forces analysis (Porter, 2008); industry driving forces analysis (Thompson et al., 2010); industry key success factors analysis (Thompson et al., 2010); and industry value chain analysis (Porter, 1985) and an industry issues analysis (M. Ungerer et al., 2016a).

Understanding the competitive positions and potential strategic moves of competitors in a competitive space creates insights on an organisation's own strategic options and choices. Competitive intelligence can be gained through a general competitive analysis (M. Ungerer et al., 2016a), a strategic competitor group map analysis (Volberda et al., 2011; Thompson et al., 2010), profiling competitors reflecting their strategic intent and scope, growth aspirations, and potential strategic moves (M. Ungerer et al., 2016a), and a competitive relative evaluation against the industry success factors (Thompson et al., 2010). A competitor analysis can also include an exploration of coopetition possibilities (Ritala \& Tidström, 2014).

The dot-com crash of 2000 reminds us of the importance of attracting and retaining repeat paying customers for a business to survive in a competitive arena (Porter, 2001; Van der Heijden, 2001). Meeting, exceeding, and anticipating customer needs and trends (Christensen, Johnson, \& Rigby, 2002; Magretta, 2002) 
using a customer-centric view (Seybold, 2001) are part of an on-going strategising process. Frameworks that can be used to stimulate customer insights are customer economic value progression (Pine \& Gilmore, 1999); e-customer demands (Ungerer, 2015); market segmentation (Fullerton, 2016; Ries \& Trout, 2011); customer empathy map (Osterwalder \& Pigneur, 2009); customer channel phases (Ungerer, 2015); and customer relationships analysis (Seybold, 2001; Ungerer, 2015).

Analysing the internal environment of an organisation is also part of Building block 2.

The internal environment of an organisation represents the strategic arena that is under full control of the leadership and this strategic space represents both the resource strengths and weaknesses of an organisation. The internal analysis builds on the external analysis as described above. In an internal analysis, the focus is on highlighting the resources competitiveness of an organisation and its internal value chain, its financial viability and track record, governance, and finally its internal risks and mitigation actions. Frameworks and tools include developing a resource-based view of strategy by doing a core and distinctive competence analysis (Hamel \& Prahalad, 1990; Hamel, 1994; Long \& Vickers-Koch, 1995); an internal value chain analysis (Porter, 1985; Thompson et al., 2010; Volberda et al., 2011); analysing organisation culture as a source for competitive advantage (Barney, 1991); a six capitals analysis (IIRC, 2013); a financial analysis (Thompson et al., 2010); a governance analysis (IODSA, 2016; M. Ungerer et al., 2016a); and an internal risk analysis (Collins \& Hansen, 2011; M. Ungerer et al., 2016a; Upton \& Creese, 2014).

\section{Building Block 3: Strategy Development: Core Strategic Options and Choices to Inform Business Model Choices}

In Figure 1, strategy development is positioned as the central strategic process that informs and is formed by four related strategic building blocks (external and internal strategic landscape factors, multiple futures, strategy execution, and strategy renewal realities). This implies that strategy formulation and development cannot be done in isolation and are linked to other building blocks in the strategic architecture. Central to the definition of strategy as discussed above is the capability of leaders in an organisation to make sound and well-founded strategic choices. The strategic choice domains related to strategy formulation and competitive positioning are reflected in Figure 3.

The three main strategic choice domains for the strategy development process building block in a strategic architecture perspective are described next.

The first category of strategic choices relates to the identity choices of an organisation and represents descriptions or narratives on the aspirational agenda of an organisation. The strategic aspirations of an organisation manifest in articulations about the vision, mission and values of the institution (Thompson et al., 2010; Volberda et al., 2011). The aspirational and identity descriptions of an organisation set the boundaries of the strategic (vision and mission) and moral (values) landscape in which it wants to operate. These descriptions relate to the basic reason for being and represent future ideal and guiding aspirations for an organisation-its core business philosophy. The main questions to explore around organisational identity are: Who are we as an organisation? And who do we want to be? The strategic choices associated with these decisions have a direct impact on the chosen strategic landscape or playing field of an organisation and the values that are emphasised and represent lead indicators on how the game of business will be played and what moral boundaries exist (M. Ungerer et al., 2016b). 


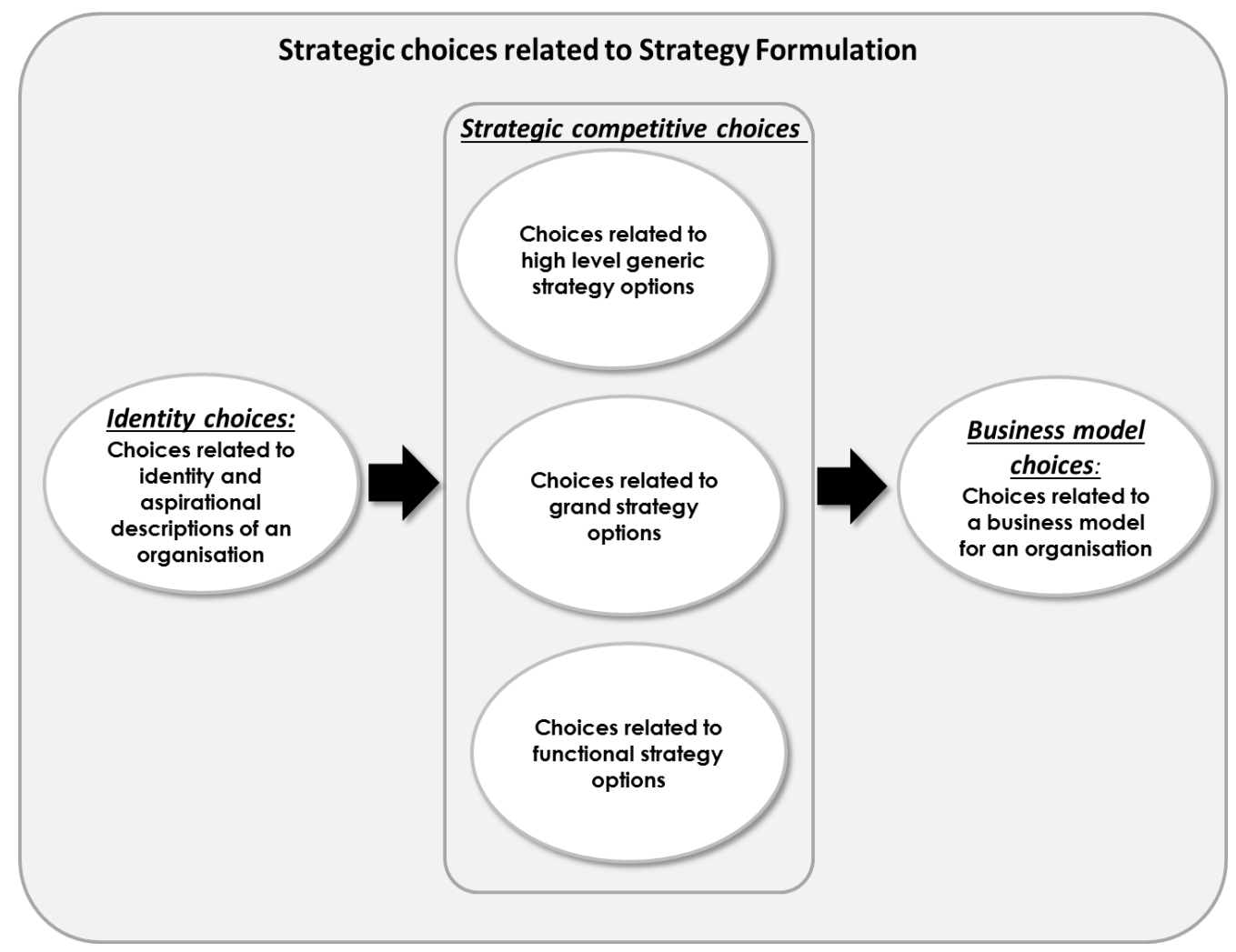

Figure 3. Strategy formulation strategic choice domains (Author's own).

Formulating the aspirational statements for an organisation on its own will not position an institution for competitive benefits, but it can certainly have a constraining effect or lead one up the wrong paths to unprofitable businesses and lost opportunities. Eloquent aspirational descriptions of an organisation alone are however not sufficient for competitive success. In other words, just having challenging aspirations (and communicating them extremely well and often) is not enough.

The embedding of organisational values as part of the individual and team performance enhancement system of an organisation is a best practice. The revitalisation and ongoing socialising of these aspirational descriptions with newcomers, new stakeholders, and new partners through various interaction mechanisms is an ongoing quest of strategic leadership (Kotter, 1996; 2014; Lipton, 2004).

Once the aspirational descriptions of an organisation have been developed, these must be translated into holistic guiding views of the strategic orientation of the firm. Only then can other strategy execution processes kick in (see Building block 5). This implies that the longer-term strategic goals of an organisation should be based on a set of core strategic choices about how the firm plans to best compete in a chosen marketplace.

The second set of strategic choices includes a menu of strategic competitive choices for an organisation that strategists and leaders should ponder as part of a strategy formulation and development process (see Figure 4). The strategic competitive choice options of an organisation can be classified into four levels: (1) identity and aspirational strategic choices (as described above); (2) generic strategy choices, e.g., competitive positioning choices (Porter, 1980; 1996; 1998), value discipline choices (Treacy \& Wiersema, 1993), digital/physical orientation choices (Ungerer, 2015), industry-based strategic style choice (Reeves, Love, \& Tillmanns, 2012), foreign market entry options (Radder \& Louw, 1998; Schaan, 2008; Volberda et al., 2011); 
(3) grand strategy choices (Pearce \& Robinson, 2009); and (4) functional strategy choices (Thompson et al., 2010). The details of generic strategies, grand strategy options and functional strategies are beyond the scope of this paper, but some features are shown in Figure 4 (M. Ungerer et al., 2016b, p. 72).

The menu of strategic competitive choices described in Figure 4 is used to stimulate dialogue as part of an ongoing strategy conversation to deepen understanding of the competitiveness of an organisation's strategy. However, this menu does not imply that the strategic options and choices indicated in Figure 4 represent all the strategic decisions related to competitive strategy positioning.

The third category of strategic choices leaders need to consider relates to the business model of an organisation (see Figure 3). A business model, as its name indicates, is a model, an abstraction or a representation of the value creation and value capturing logic of the business (Magretta, 2002; Teece, 2010). Business models and strategies broadly revolve around the same concepts but exist at different levels of abstraction. Strategy can be seen as a domain, whereas a business model is a tool relevant to the domain. Strategy is a more high-level, over-arching, broad, intangible and soft concept; whereas business models are more specific and tangible, yet still conceptual. The relationships between strategy, business models and operations are depicted in Figure 5.

Strategy places more emphasis on issues regarding the core aspirational description of a business (vision, mission, values, and goal-setting), its competitive positioning and environment, competitors and competition, value capturing, and the creation of a competitive advantage (Magretta, 2002; Mansfield \& Fourie, 2004; Zott, Amit, \& Massa, 2011). Business models, on the other hand, are mainly concerned with customers, value creation, cooperation and partnerships, and the means by which the business sustains itself (Mansfield \& Fourie, 2004; Osterwalder, 2004). Business models seek to depict the way that value is created and delivered to customers, and how revenue is generated. A business model is therefore the strategy of the business distilled into a conceptual blueprint of its value creation and capturing logic (Osterwalder, 2004; Osterwalder \& Pigneur, 2009; Teece, 2010; Ungerer, 2015).

Leaders need to make business model choices about the following twelve strategic aspects of an organisation: customer retention, targeted customer segments, customer relationships, delivery channels, value propositions, key activities in an activity system, key resources, key partners, key metrics, cost structures, revenue streams, and the competitive advantage of the organisation (Osterwalder, 2004; Osterwalder \& Pigneur, 2009; M. Ungerer et al., 2016b, p. 126). The strategic choices and decisions about the different business model components cannot be made in isolation because they are systemically interrelated and informed by the other strategic architecture building blocks (see Figure 1).

\section{Building Block 4: Development of Multiple Future Views}

At the very core of strategy work is the realisation that an organisation is, at any one moment in its life, faced by many possible futures. Scenarios constitute a way of thinking more comprehensively about the future - to learn from the future. Scenario building and planning establish a visual interactive dialogue process to develop innovative foresight (Hiltunen, 2013). Peter Schwartz (1996, p. 4) defined scenarios as a "tool for ordering one's perceptions about alternative environments in which one's decisions might be played out". Hamel (2000) reminded us that the problem with the future is that it will be different. Learning about possible futures, and the signposts en route to these futures, enables decision-makers to manage long-term risks better and proactively seize emerging opportunities (M. Ungerer et al., 2016b). 


\section{A Menu of Strategic Competitive Choices}

Identity and aspirational descriptions for organisations - Level 1 Strategic choices

$$
\text { - Vision } \cdot \text { Mission } \quad \text { Values }
$$

Generic strategies for organisations - Level 2 Strategic choices

\begin{tabular}{l} 
Generic \\
competitive \\
strategy options \\
Overall cost \\
leadershipstrategy \\
- Focused cost \\
leadership strategy \\
Broad differentiation \\
strategy \\
Focused \\
differentiation \\
strategy \\
Integrated cost and \\
differentiation \\
strategy \\
\hline
\end{tabular}

\begin{tabular}{|l|l|}
$\begin{array}{l}\text { The value } \\
\text { disciplines }\end{array}$ & $\begin{array}{l}\text { Digital/Physical } \\
\text { orientation }\end{array}$ \\
\hline $\begin{array}{l}\text { Operational } \\
\text { xcellence }\end{array}$ & $\begin{array}{l}\text { Digital pure play } \\
\text { Customer intimacy } \\
\text { Product leadership }\end{array}$ \\
\hline $\begin{array}{l}\text { Physical pure play } \\
\text { Digital pure play with } \\
\text { physical products }\end{array}$ \\
\hline
\end{tabular}

\begin{tabular}{|l|l|}
$\begin{array}{l}\text { Industry-based } \\
\text { strategic styles }\end{array}$ & $\begin{array}{c}\text { Strategic posture } \\
\text { options }\end{array}$ \\
\hline $\begin{array}{l}\text { A classical strategy } \\
\text { An adaptive strategy } \\
\text { A shaping strategy } \\
\text { A visionary strategy }\end{array}$ & $: \begin{array}{l}\text { Conservative posture } \\
\text { Aggressive posture } \\
\text { Defensive posture } \\
\text { Competitive posture }\end{array}$ \\
\hline
\end{tabular}

Foreign market entry options

Grand strategies for organisations - Level 3 Strategic choices

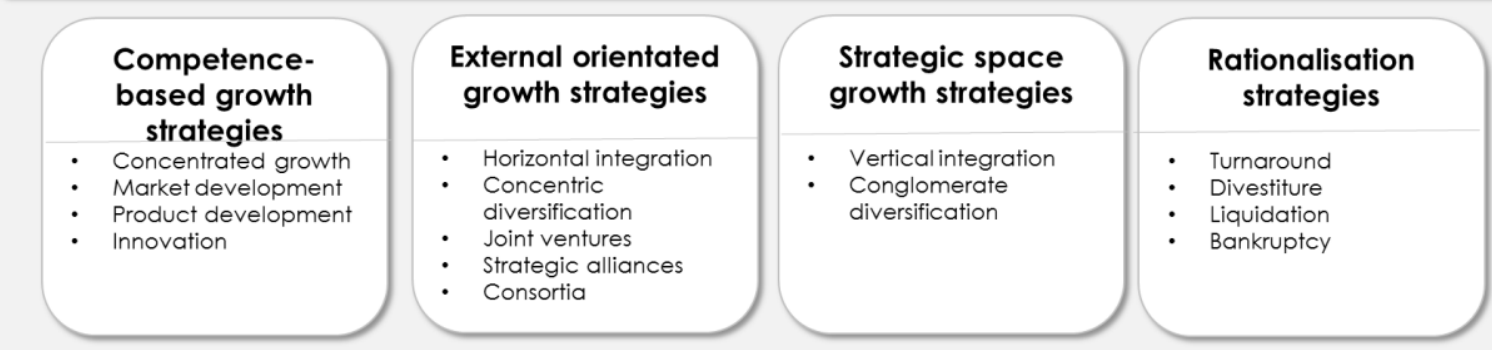

Functional strategies to support Generic and Grand strategies - Level 4 Strategic choices 


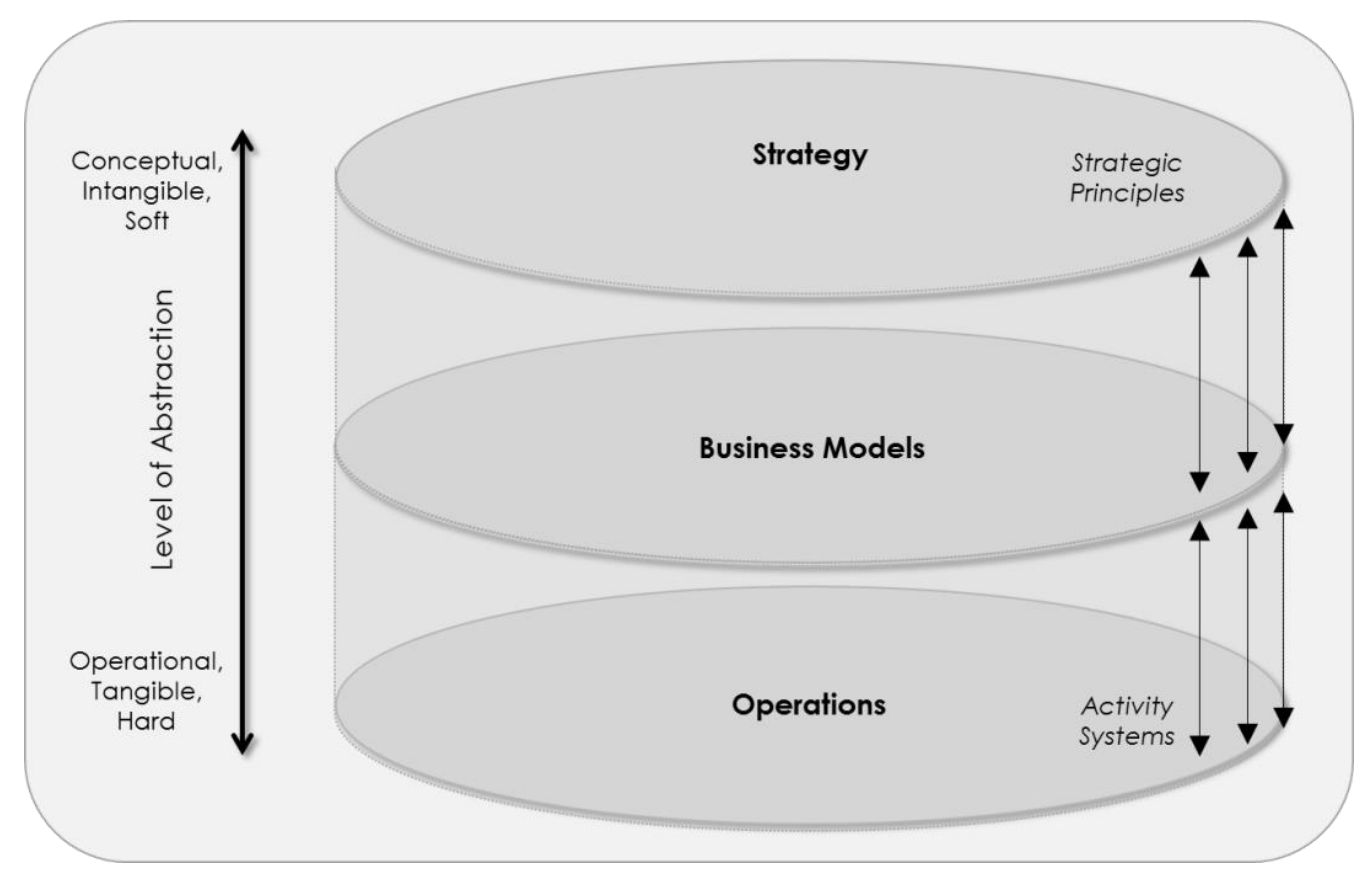

Figure 5. Conceptual relationships between strategy, business models, and operations (Author's own).

The objective of the scenario-building process is two-fold. First, by looking into the future with all its uncertainties, it is a sense-making exercise to better understand the status quo. Second, it is a tool for long-term strategic direction setting (Vorster, Ungerer, \& Volschenk, 2013).

Research indicates that exposing decision-makers to scenario development processes significantly enhances their ability to deal with uncertainty (Varum \& Melo, 2010). Varum and Melo (2010) had also found that the main benefits of using scenarios are improvement of the decision-making process and the identification of new issues and problems that may arise in the future. Other researchers report a reduction in over-confidence bias by challenging prevailing mind-sets (Schoemaker, 1993), a reduction in the framing bias where both positive and negative effects are considered (Meissner \& Wulf, 2012), and a reduction in the confirmation bias by being exposed to a variety of data (Bradfield, 2008). Chermack (2013) showed that scenarios assist in influencing a broad range of mental models held by decision-makers.

Well-developed and thought-through scenarios focus the minds of decision-makers on the most critical decisions required to "nudge" the organisation towards a more desired future, given the assumptions and information underlying the possibility spaces created by the scenarios.

\section{Building Block 5: Strategy Execution: Translation, Mobilisation and Monitoring}

Strategic thinking as described in strategic Building Blocks 1-4 above needs to be translated into strategic action to ensure the implementation of strategy. Research (Kaplan \& Norton, 2008; Neilson, Martin, \& Powers, 2008; PwC, 2014) showed that organisations generally struggle to implement their strategies because of multiple challenges - ranging from, inter alia, a lack of tangible strategic planning processes, resource constraints, lack of focus and prioritisation, to organisation culture, e.g., low action orientation and destructive internal competition.

The imperatives for excellent strategy execution capabilities in a fast-changing world are clear. Organisations that execute first, win, and a well-entrenched strategy execution capability has become a 
competitive advantage (Bossidy, Charan, \& Buck, 2002; Kaplan \& Norton, 2001; Mankins \& Steele, 2005).

The integration of the strategy-making and the strategy execution processes is shown in Figure 6. The key elements in strategy translation, mobilisation, and monitoring are also reflected in Figure 6, but the detail is beyond the scope of this paper.

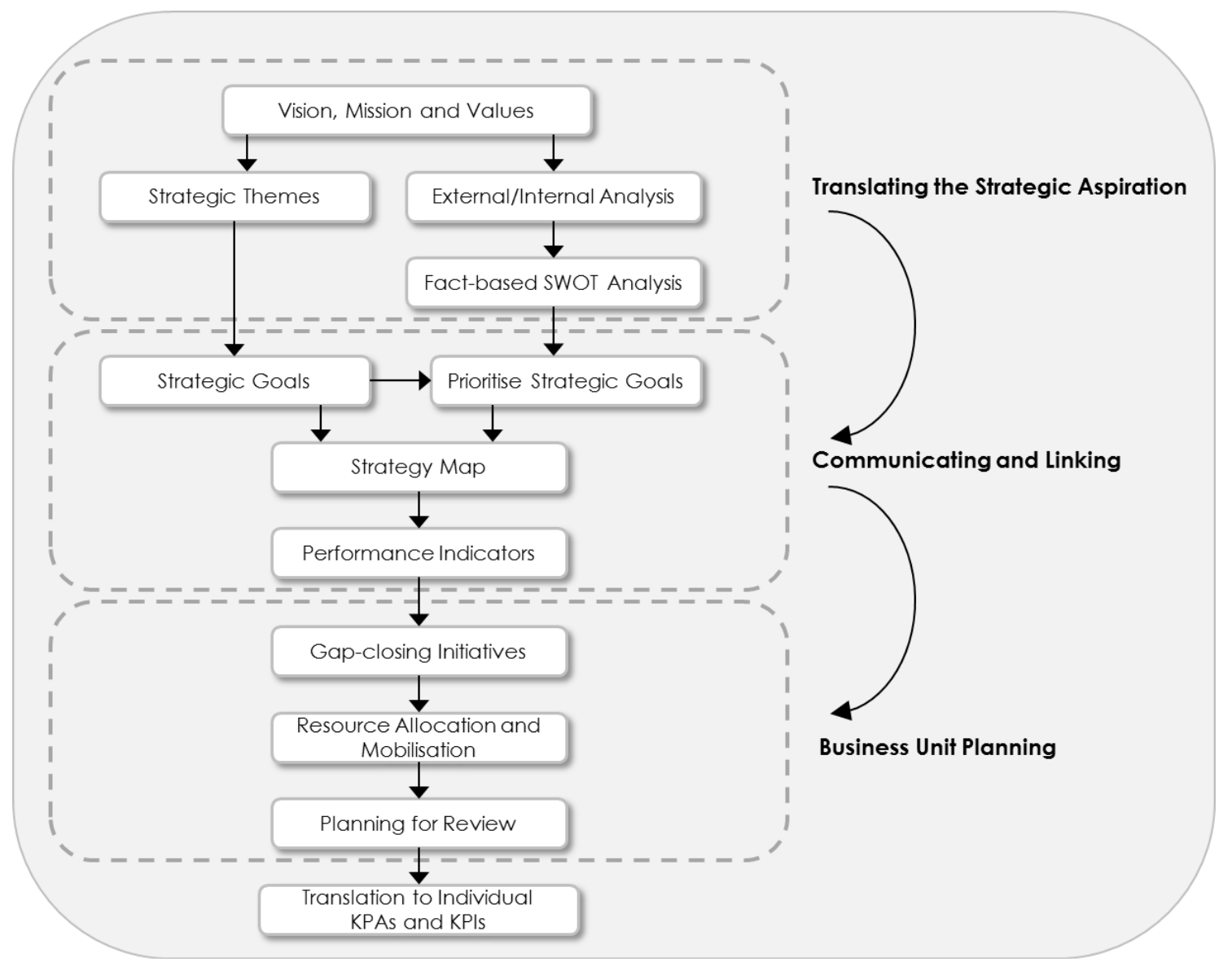

Figure 6. Strategy translation, mobilisation and monitoring (Author's own).

Strategy tools and processes that enable strategy execution are the following: a strategy map reflecting key strategic goals and measurements; a balanced scorecard indicating enterprise-wide strategic measurements to achieve the aspirations of the organisation; a strategic business plan showing the key strategic initiatives within a time scope (short-, medium- or long- term); an enterprise business performance monitoring process that includes quarterly dialogues at enterprise and business unit levels to evaluate progress and initiate proactive corrective actions, if required; and finally, an individual performance management system to link strategic goals and initiatives to individual KPAs (Kaplan \& Norton, 1996; 2001; 2005; 2008; Neilson et al., 2008; D. Sull, Holmes, \& C. Sull, 2015).

\section{Building Block 6: Strategy Renewal and Innovation}

The continuous reinvention of an organisation to stay relevant in its chosen strategic landscape is at the centre of sustainable competitiveness. Reasons for the high obsolescence rate of business models can be found in the ongoing significant changes in external business environments-increased consumer activism; on-going new technology inventions and innovations; the heightened impact of special interest groups (e.g., 
environmental activists and religious fundamentalists); the struggle for political power between traditionally rich and poor countries; and increased pressures on global trade barriers and incentives. Organisational strategies need to reflect the realities of both local circumstances and emerging global patterns - a very tall order indeed. Rosenzweig (2007, p. 104) reminded us that "high performance is difficult to maintain, ... high profits tend to decline ... Rivals copy the leader's winning ways, new companies enter the market, consulting companies spread best practices, and employees move from company to company". He explained that risks are related to uncertain customer demands, unpredictable competition, and changing technology (Rosenzweig, 2007, pp. 145-147).

The continuous development and broadening of the variety of strategic options and choices for a business to consider are part of its strategic innovation process to create an internal market for ideas. This flow of ideas creates a portfolio of innovative concepts, experiments, and new ventures (Hamel, 2000). To stimulate new thinking on current strategies, a variety of strategy innovation tools and frameworks is available, for example, Blue Ocean strategy (Kim \& Mauborgne, 2004; 2005; 2017), business model innovation (Casadesus-Masanell \& Ricart, 2011; Johnson et al., 2008; Lee \& Vonortas, 2004; Teece, 2010; Zook \& Allen, 2011 ), sources of e-value (Amit \& Zott, 2001; Anderson \& Srinivasan, 2003; Ungerer, 2015; M. Ungerer et al., 2016b), new market-space creation (Kim \& Mauborgne, 1999; Ungerer et al., 2011), breaking through stall-points and decline (Collins, 2009; Collins \& Hansen, 2011; Olson, Van Bever, \& Verry, 2008), and the development of inorganic growth strategies through alliances and mergers and acquisitions (M\&As) (Armour, 2002; Epstein, 2004; Ficery, Herd, \& Purche, 2007; M. Ungerer et al., 2016b). Another essential part of the strategy renewal agenda of organisations is to inspire leadership thinking with ideas on how to innovate current management practices to ensure an alignment with a changing strategic context and workforce expectations (Birkinshaw \& Mol, 2006; Birkinshaw, Hamel, \& Mol, 2008; Hamel, 2007, 2009,2012; Wheatley, 2007).

The above internal-focused innovation and renewal process needs to be aligned with the opportunities and threats associated with the external environment scan (Building Block 2), the views about likely future scenarios (Building Block 4) and the internal resources, strengths and weaknesses of the organisation (Building Block 2).

\section{Building Block 7: Entrepreneurial Leadership}

The building blocks of a strategic architecture perspective (see Figure 1) are anchored in strategic leadership and entrepreneurial thinking and practices. The strategic entrepreneurship perspective on strategy integrates opportunity seeking as the simultaneous consideration of an organisation's initial internal situation and external opportunities to gain competitive advantage (Hitt, Ireland, Camp, \& Sexton, 2001; Ireland \& Hit, 1999; Ireland, Hitt, \& Sirmon, 2003). Discovery theory and creation theory are both used to explain how entrepreneurs take action to form and exploit opportunities (Alvarez \& Barney, 2007). Discovery theory states that a heightened alertness by entrepreneurs about exogenous shocks, such as changes in competition, technology, and customer preferences is used to stimulate opportunity seeking, while creation theory indicates that entrepreneurial action is endogenously created by exploring ways to produce new products or services.

This strategic architecture building block also supports both entrepreneurship and intrapreneurship orientations as drivers of economic growth (Audretsch, Keilbach, \& Lehmann, 2006; Van Praag \& Versloot, 2007). Entrepreneurship represents activities like starting a new venture with the associated risks and rewards of being an owner, while an intrapreneurship orientation promotes entrepreneurial activities within the 
boundaries of an existing business to turn an idea into a profitable finished product or service through assertive risk-taking and innovation (Barringer \& Bluedorn, 1999; Lynch, 2009; Pinchot, 1984).

\section{Discussion of Strategic Architecture Features}

Strategy praxis involves diverse conversations and interaction episodes between stakeholders of an organisation (Jarzabkowski \& Spee, 2009). A strategic architecture perspective on an organisation assists and stimulates dialogues about the various aspects of the building blocks and their inter-relatedness. The idea is to use the strategic architecture building blocks as a reference baseline to facilitate critical reflections on strategic choices and execution progress for motivating on-going improvements and facilitating stakeholder alignment. When innovations on aspirational descriptions, business models, and competitive re-positioning are considered, the strategic architecture baseline is used to evaluate strategic viability, fit, and alignment.

At first glance a strategic architecture view might look overwhelming and complicated. The creation of the different building blocks and the deepening of the strategy praxis in these domains is not a one-time event but developed over time within the strategic rhythm of the organisation as influenced by its leadership preferences, strategic cycle, stage, and needs.

The strategic architecture perspective as described here should not be viewed as a framework for hard strategy work based on "hard data from market research" only (Mintzberg, 1994b, p. 12). It highlights the "social side of strategy" (Bradley, Hirt, \& Smit, 2018, p. 1) through a focus on strategic leadership (Building Block 1) as the key to making strategy alive and to mobilising people for involvement and participative decision-making, e.g., during strategy translation events. Other softer strategy issues are also addressed through an entrepreneurial strategy thinking approach (Building Block 7) that fosters a dynamic can do attitude where obstacles are turned into possibilities and both incremental and radical innovation is promoted. Exposure to scenarios development processes (Building Block 4) sensitises decision-makers to a range of cognitive biases, such as over-confidence, framing, and confirmation. A market-focused strategy needs to be underpinned by cold, hard numbers, and business facts, as well as involved and motivated people with a thorough understanding of the strategic intent and goals of the organisation. The strategic architecture perspective promotes a strategy process that embraces both a data- and fact-based outside view (Building Blocks 2 and 6) and a sensitivity towards the collective side of strategy. Mintzberg (1994a, p. 114) cautioned us about the "need to loosen up the process of strategy making rather than trying to seal it off by arbitrary formalization".

A strategic architecture view is more suitable for organisations with a focused business portfolio with related core business lines than diversified conglomerate business portfolios with low inter-dependencies. This is because leveraging internal resource synergies and capabilities to support multiple end-markets based on a shared strategic orientation galvanises strategic efforts and impact. Neither the need to share resources nor a common strategic focus and orientation is prevalent in diversified conglomerate portfolios-a key assumption in creating a shared view on a strategic architecture for an organisation.

A strategic architecture perspective can be developed for both profit and not-for-profit organisations if the leadership aspiration and will exist to create and deliver outputs to meet and exceed stakeholder needs and expectations. Even if the objective is not to make a profit, every organisation has a purpose that encapsulates its reason for being. It must plan strategically to achieve this purpose.

Research (Ungerer, 2013; Ungerer \& Vorster, 2015) on the use of the elements of a strategic architecture perspective by JSE-listed companies in six industry clusters (banking, construction, energy, insurance, mining 
and retail), as reported in their annual and integrated reports, indicate a relatively high usage and disclosure level of 67 per cent. This means that for the six industry clusters combined, companies are disclosing on average about 67 per cent of the potential aspects associated with a strategic architecture perspective. Strategy architecture disclosure indicators that are under-reported include competitive strategy and strategy execution details. This is understandable, because a too open strategy disclosure approach can arguably involve risks, such as diluting competitive advantage, for example, disclosed information on strategy could be used by a company's competitors to outmanoeuvre them, or to pre-empt first-mover advantage. A strategic architecture perspective as described in this paper should be used externally in the public domain with due care not to forego strategic competitive advantages.

\section{Conclusions}

Winston Churchill (1997) once said: "It is not enough that we do our best; sometimes we need to do what's required" (p. 5). In a complex business world, we need to seek solutions at a higher level of complexity to first make conceptual progress before operational progress. A strategic architecture perspective assists leaders to work through the strategic complexity to arrive at simplicity in the form of clarity on external and internal strategic leverages, strategic aspirations, core strategic choices, plausible multiple scenarios, focused strategic goals, and success measurements to guide strategy execution and ongoing strategy renewal and innovations for proactive strategic decision-making through various dialogues with key stakeholders.

In this paper, the arguments highlight the following key assertions:

1. Strategic architecture increases the chances of organisational success. A strategic architecture view on an organisation facilitates alignment and focus on the core strategic choices the organisation makes to achieve success. The successful execution of both planned and emergent strategies relies on clarity about the future strategic aspirations and options of an organisation.

2. Thorough analyses enhance the robustness of a strategic architecture. An organisation's strategy formulation and development cycle should at least be informed by a thorough fact-based external and internal analysis. As the strategy practices of an organisation mature over time, multiple strategy building-block domains, as described above, will inform and shape the strategy development process cycle.

3. Resource capabilities are key to the strategic architecture. Organisations achieve their ultimate ambitions through their internal resource capabilities to execute their strategic plans. The resources at an organisation's disposal represent their action potential — setting the boundaries for strategic moves to consider (Tilles, 1963).

4. People make or break strategies. It is imperative to foster a people-centric approach during strategising processes, practices, and praxis to ensure maximum support, enthusiasm, and momentum for the strategic journey.

5. Thinking paradigms dominate. The dominant paradigm of the strategy-makers will have a decisive influence on how - and by whom - strategy is made. Strategic and entrepreneurial leadership are key enablers that infuse energy, perspective, and ambition into the strategic development and execution journey of an organisation.

6. An effective strategic architecture will move organisational thinking to a higher level. Strategy and the disciplines associated with "good" strategy-making, as described in this paper, still form the basis for moving organisations to a higher level of conceptual and pragmatic understanding of their current realities and future 
aspirations and possibilities. Strategy, as the act of producing greater certainty for stakeholders at any point in time on what to expect and do, is necessary but not sufficient for organisational survival. We need leaders with the necessary wisdom who display both the moral will and the moral skill to lead us into an uncertain future (where there are fewer guarantees).

\section{References}

Alvarez, S. A., \& Barney, J. B. (2007). Discovery and creation: Theories of entrepreneurial action. Strategic Entrepreneurship Journal, 1(1-2), 1-26.

Amit, R., \& Zott, C. (2001). Value creation in e-business. Strategic Management Journal, 22(6-7), 493-520.

Andersen, T. J. (2000). Strategic planning, autonomous actions and corporate performance. Long Range Planning, 33(2), $184-200$. Retrieved on April 23, 2015 from http://www.elsevier.com/locate/lrp0024-6301/

Anderson, R., \& Srinivasan, S. (2003). E-satisfaction and e-loyalty: A contingency framework. Psychology \& Marketing, 20(2), 123-138.

Armour, E. (2002). How boards can improve the odds of M \& A success. Strategy \& Leadership, 30(2), 13-20.

Audretsch, D. B., Keilbach, M. C., \& Lehmann, E. E. (2006). Entrepreneurship and economic growth. Oxford: Oxford University Press.

Badaracco, J. L. (2001). We don't need another hero. Harvard Business Review, 79(8), 120-126.

Barney, J. B. (1991). Firm resources and sustainable competitive advantage. Journal of Management, 17(1), 99-120.

Barringer, B. R., \& Bluedorn, A. C. (1999). The relationship between corporate entrepreneurship and strategic management. Strategic Management Journal, 20(5), 421-444.

Birkinshaw, J., \& Mol, M. (2006). How management innovation happens. MIT Sloan Management Review, 47(4), 81-88.

Birkinshaw, J., Hamel, G., \& Mol, M. (2008). Management innovation. Academy of Management Review, 33(4), 825-845.

Bolden, R. (2011). Distributed leadership in organizations: A review of theory and research. International Journal of Management Reviews, 13(3), 251-269.

Bossidy, L., Charan, R., \& Buck, C. (2002). Execution: The discipline of getting things done. New York, NY: Crown Business.

Bradfield, R. (2008). Cognitive barriers in the scenario development process. Advances in Developing Human Resources, 10(2), 198-215.

Bradley, C., Hirt, M., \& Smit, S. (2018). Strategy to beat the odds. McKinsey Quarterly, February, 1-11.

Büschgens, T., Bausch, A., \& Balkin, D. B. (2013). Organizing for radical innovation: A multi-level behavioral approach. The Journal of High Technology Management Research, 24(2), 138-152.

Cameron, K. (2011). Responsible leadership as virtuous leadership. Journal of Business Ethics, 98(1), 25-35.

Casadesus-Masanell, R., \& Ricart, J. E. (2011). How to design a winning business model. Harvard Business Review, 89(1-2), 102-109.

Chermack, T. J. (2013). Drivers and outcomes of scenario planning: A canonical correlation analysis. European Journal of Training and Development, 37(9), 811-834.

Chia, R. C. H., \& Holt, R. (2011). Strategy without design. Cambridge: Cambridge University Press.

Christensen, C. M., \& Overdorf, M. (2000). Meeting the challenge of disruptive change. Harvard Business Review, 78(2), 66-76.

Christensen, C. M., \& Raynor, M. E. (2003). Why hard-nosed executives should care about management theory. Harvard Business Review, September, 81(9), 67-74.

Christensen, C. M., Johnson, M. W., \& Rigby, D. K. (2002). Foundations for growth: How to identify and build disruptive new businesses. MIT Sloan Management Review, 43(3), 21-31.

Churchill, W. (1997). Winston Churchill quotations. Norwich: Jarrold Publishing.

Collins, J. (2001). Good to great: Why some companies make the leap and others don't. London: Random House.

Collins, J. (2009). How the mighty fall and why some companies never give in. New York, NY: Harper Collins.

Collins, J., \& Hansen, M. T. (2011). Great by choice: Uncertainty, chaos, and luck-Why some survive despite them all. New York, NY: Harper Business.

Covin, J. G. (1991). Entrepreneurial versus conservative firms: A comparison of strategies and performance. Journal of Management Studies, 28(5), 439-462.

De Wit, B., \& Meyer, R. (2014). Strategy: An international perspective (5th ed.). Hampshire: Cengage Learning.

Drucker, P. F. (1986). Management: Tasks, responsibilities, practices. New York, NY: Truman Talley Books. 
Dubin, R. (1976). Theory building in applied areas. In M. D. Dunnette (Ed.), Handbook of industrial and organisational psychology (pp. 7-39). New York, NY: Wiley.

Eisenhardt, K. M. (1989). Making fast strategic decisions in high-velocity environments. Academy of Management Journal, 32(3), 5430-5476.

Epstein, M. J. (2004). The drivers of success in postmerger integration. Organizational Dynamics, 33(2), 174-189.

Falshaw, J., Glaister, K., \& Tatoglue, E. (2006). Evidence on formal strategic planning and company performance. Management Decision, 44(1), 9-30. Retrieved on March 27, 2015 from http://dx.doi.org/10.1108/00251740610641436

Ficery, K., Herd, T., \& Purche, B. (2007). Where has all the synergy gone? Journal of Business Strategy, 28(5), 29-35.

Frankl, V. E. (2006). Man's search for meaning: An introduction to logotherapy. Boston, MA: Beacon Press.

Fullerton, R. (2016). Segmentation in practice: An overview of the eighteenth and nineteenth centuries. In D. G. B. Jones and M. Tadajewski (Eds.), The Routledge companion to marketing history. Oxon: Routledge.

Galbreath, J., \& Galvin, P. (2008). Firm factors, industry structure and performance variation: New empirical evidence to a classic debate. Journal of Business Research, 61, 109-117.

Grant, R. M. (1991). The resource-based theory of competitive advantage: Implications for strategy formulation. California Management Review, 33(3), 114-135.

Grant, R. M. (2016). Contemporary strategy analysis (9th ed.). Chichester: Wiley.

Grant, R. M., \& Jordan, J. (2015). Foundations of strategy (2nd ed.). Chichester: Wiley \& Sons.

Hakimpoor, H. (2014). Strategic planning process-Dimensions and SMEs performance. Proceedings of 10th Global Business and Social Science Research Conference, 23-24 June 2014, Radisson Blu Hotel, Beijing, China.

Hamel, G. (1994). The concept of core competence. In G. Hamel and A. Heene (Eds.), Competence-based competition (pp. 1-33). Chichester, UK: John Wiley.

Hamel, G. (1996). Strategy as revolution. Harvard Business Review, July-August, 69-82.

Hamel, G. (2000). Leading the revolution. Boston: Harvard Business School Press.

Hamel, G. (2007). The future of management. Boston: Harvard Business School Press.

Hamel, G. (2009). Moon shots for management. Harvard Business Review, 87(2), 91-98.

Hamel, G. (2012). What matters now: How to win in a world of relentless change, ferocious competition, and unstoppable innovation. San Francisco: Jossey-Bass.

Hamel, G., \& Prahalad, C. K. (1989). Strategic intent. Harvard Business Review, May/June, 63-76.

Hamel, G., \& Prahalad, C. K. (1990). The core competence of the corporation. Harvard Business Review, May/June, 1-15.

Hart, S. L., \& Milstein, M. B. (2003). Creating sustainable value. Academy of Management Executive, 17(2), 56-67.

Hiltunen, E. (2013). Foresight and innovation: How companies are coping with the future. New York, NY: Palgrave Macmillan.

Hitt, M. A., Ireland, R. D., Camp, S. M., \& Sexton, D. L. (2001). Guest editors' introduction to the special issue strategic entrepreneurship: Entrepreneurial strategies for wealth creation. Strategic Management Journal, 22(6/7), 479-491.

Institute of Directors SA (IODSA). (2016). KIng IV Report on Corporate Governance for South Africa. Retrieved from http://c.ymcdn.com/sites/www.iodsa.co.za/resource/collection/684B68A7-B768-465C-8214-E3A007F15A5A/IoDSA_King_ IV_Report_-_WebVersion.pdf

International Integrated Reporting Council (IIRC). (2013). Capitals: Background paper. Retrieved on February 2, 2017 from https://integratedreporting.org/wp-content/uploads/2013/03/IR-Background-Paper-Capitals.pdf

Ireland, R. D., \& Hit, M. A. (1999). Achieving and maintaining strategic competitiveness in the 21st century: The role of strategic leadership. Academy of Management Executive, 13(1), 63-77.

Ireland, R. D., Hitt, M. A., \& Sirmon, D. G. (2003). A model of strategic entrepreneurship: The construct and its dimension. Journal of Management, 29(6), 963-989.

Jarzabkowski, P., \& Spee, A. P. (2009). Strategy-as-practice: A Review and future directions for the field. International Journal of Management Reviews, 11(1), 69-95.

Johnson, M. W., Christensen, C. M., \& Kagermann, H. (2008). Reinventing your business model. Harvard Business Review, 86(12), 57-68.

Kaplan R. S., \& Norton, D. P. (2001). The strategy-focused organization. Boston, MA: Harvard Business School Press.

Kaplan, R. S., \& Norton, D. P. (1996). The Balanced Scorecard: Translating strategy into action. Boston, MA: Harvard Business School Press.

Kaplan, R. S., \& Norton, D. P. (2008). The execution premium. Boston: MA: Harvard Business School Publishing. 
Kaplan, R.S., \& Norton, D.P. (2005). Focusing your organization on strategy-with the Balanced Scorecard (3rd ed.). Boston: Harvard Business School Press.

Kerssens-van Drongelen, I. (2001). The iterative theory-building process: rationale, principles and evaluation. Management Decision, 39(7), 503-512.

Kiernan, M. J. (1993). The new strategic architecture: Learning to compete in the twenty-first century. Academy of Management Executive, 7(1), 7-21.

Kim, W. C., \& Mauborgne, R. (1999). Creating new market space. Harvard Business Review, 77(1), 83-93.

Kim, W. C., \& Mauborgne, R. (2004). Blue Ocean strategy. Harvard Business Review, 82(10), 76-84.

Kim, W. C., \& Mauborgne, R. (2005). Blue Ocean strategy. Boston: Harvard Business School Press.

Kim, W. C., \& Mauborgne, R. (2017). Blue Ocean shift: Beyond competing. New York, NY: Hachette Books.

Koberg, C. S., Detienne, D. R., \& Heppard, K. A. (2003). An empirical test of environmental, organizational, and process factors affecting incremental and radical innovation. The Journal of High Technology Management Research, 14(1), 21-45.

Kotter, J. P. (1996). Leading change. Boston: Harvard Business School Press.

Kotter, J. P. (2014). Accelerate: Building strategic agility for a faster-moving world. Boston: Harvard Business Review Press.

Lee, C. S., \& Vonortas, N. S. (2004). Business model innovation in the digital economy. In G. Doukidis, N. Mylonopoulos, and N. Pouloudi (Eds.), Social and economic transformation in the digital era. Hershey, PA: Idea Group.

Lipton, M. (2004). Walking the talk (really!): Why visions fail. Ivey Business Journal, 68(3), 358-364.

Long, C., \& Vickers-Koch, M. (1995). Using core capabilities to create competitive advantage. Organisational Dynamics, 24(1), 6-22.

Lovallo, P., \& Medona, L. T. (2007). Strategy's strategist: An interview with Richard Rumelt. The McKinsey Quarterly, August, $1-10$.

Lynch, R. L. (2009). Strategic management (5th ed.). Harlow: Financial Times Prentice Hall.

Magretta, J. (2002). Why business models matter. Harvard Business Review, 80(5), 86-93.

Magretta, J. (2012). Understanding Michael Porter. Boston: Harvard Business Review Press.

Mankins, M. C., \& Steele, R. (2005). Turning great strategy into great performance. Harvard Business Review, 83(7), 64-72.

Mansfield, G. M., \& Fourie, L. C. (2004). Strategy and business models — strange bedfellows? A case for convergence and its evolution into strategic architecture. South African Journal of Business Management, 35(1), 35-44.

Meissner, P. (2014). A process-based perspective on strategic planning: The role of alternative generation and information integration; Business Research, 7(1), 105-124.

Meissner, P., \& Wulf, T. (2012). Cognitive benefits of scenario planning: Its impact on biases and decision quality. Technological Forecasting and Social Change, 80(4), 801-814.

Mintzberg, H. (1987). The strategy concept I: Five Ps for strategy. California Management Review, 30(1), 11-24.

Mintzberg, H. (1994a). The fall and rise of strategic planning. Harvard Business Review, 72(1), 107-114.

Mintzberg, H. (1994b). Rethinking strategic planning Part I: Pitfalls and fallacies. Long Range Planning, 27(3), $12-21$.

Mintzberg, H., Ahlstrand, B., \& Lampel, J. (2009). Strategy Safari. Edinburgh Gate: Prentice Hall.

Mitchell, R. K., Agle, B. R., \& Wood, D. J. (1997). Towards a theory of stakeholder identification and salience: Defining the principle of who and what really counts. Academy of Management Review, 22(4), 853-886.

Montgomery, C. A. (2012). The strategist. London: HarperCollins.

National Development Plan (NDP). (2012). Vision 2030. Retrieved on February $2, \quad 2018 \quad$ from http://www.nationalplanningcommission.org.za/Pages/NDP.aspx

Neilson, G. L., Martin, K. L., \& Powers, E. (2008). The secrets to successful strategy execution. Harvard Business Review, 86(6), 60-70.

Olson, M. S., Van Bever, D., \& Verry, S. (2008). When growth stalls. Harvard Business Review, 86(3), 51-61.

Oosthuizen, H. (2005). The relationship between strategic process dimensions and organisational output performance-A South African investigation in relation to global best practices. South African Journal of Business Management, 36(4), 69-79.

Osterwalder, A. (2004). The business model ontology-A proposition in a design science approach. Switzerland: University of Lausanne.

Osterwalder, A., \& Pigneur, Y. (2009). Business model generation. Retrieved from http://radio.shabanali.com/business-model-generation-osterwalder.pdf

Pearce II, J. A., \& Robinson, R. B. (2009). Formulation, implementation and control of competitive strategy (11th ed.). Boston: McGraw-Hill. 
Pearce II, J. A., Freeman, E. B., \& Robinson Jr. R. B. (1987). The tenuous link between formal strategic planning and financial performance. Academy of Management, 12(4), 658-675.

Peng, M. W. (2000). Business strategies in transition economies. London: Sage Publications, Inc.

Peterson, C., \& Seligman, M. (2004). Character strengths and virtues: A handbook and classification. New York: Oxford University Press.

Pinchot, G. (1984). Who is the intrapreneur? In Intrapreneuring: Why you don't have to leave the corporation to become an entrepreneur. New York: Harper \& Row.

Pine, J., \& Gilmore, J. (1999). The experience economy. Boston: Harvard Business School Press.

Porter, M. E. (1980). Competitive strategy: Techniques for analyzing industries and competitors. New York: Free Press.

Porter, M. E. (1985). Competitive advantage. New York, NY: Free Press.

Porter, M. E. (1996). What is strategy? Harvard Business Review, 74(6), 61-78.

Porter, M. E. (1998). Competitive advantage: Creating and sustaining superior performance. New York: Free Press.

Porter, M. E. (2001). Strategy and the internet. Harvard Business Review, 79(3), 62-78.

Porter, M. E. (2008). The five competitive forces that shape strategy. Harvard Business Review, 86(1), 57-71.

Porter, M. E., \& Kramer, M. (2011). Creating shared value. Harvard Business Review, R1101C, 1-17.

Prahalad, C. K., \& Hamel, G. (1990). The core competence of the corporation. Harvard Business Review, 68(3), 79-93.

PricewaterhouseCoopers (PwC). (2014). Research on the strategy-execution gap. Retrieved on February 20,2016 from http://www.strategyand.pwc.com/global/home/what-we-think/cds_home/the_concept/research-strategy-execution-gap

Radder, L., \& Louw, L. (1998). The SPACE matrix: A tool for calibrating competition. Long Range Planning, 31(4), $549-559$.

Reeves, M., Love, C., \& Tillmanns, P. (2012). Your strategy needs a strategy. Harvard Business Review, 90(9), 7683.

Rego, A., Cunha, M. P. E., \& Clegg, S. (2012). The virtues of leadership. Oxford: Oxford University Press.

Ries, A., \& Trout, J. (2011). Market segmentation and positioning. In P. Baines, C. Fill, and K. Page (Eds.), Marketing (pp. 214-263). Oxford: Oxford University Press.

Rigby, D., \& Bilodea, B. (2015). Management tools \& trends. Bain Brief, June. Retrieved on January 18,2018 from http://www.bain.com/publications/articles/management-tools-and-trends-2015.aspx

Ritala, P., \& Tidström, A. (2014). Untangling the value-creation and value-appropriation elements of coopetition strategy: A longitudinal analysis on the firm and relational levels. Scandinavian Journal of Management, 30(4), 498-515.

Rosenzweig, P. M. (2007). The halo effect... and the eight other business delusions that deceives managers (1st ed.). New York, NY: Free Press.

Rumelt, R. P. (2011). Good strategy, bad strategy: The difference and why it matters. New York, NY: Crown Business.

Schaan, J. (2008). International strategy elective class interaction, July. Bellville, Cape Town: University of Stellenbosch Business School (USB).

Schoemaker, P. (1993). Multiple scenario development: Its conceptual and behavioral foundation. Strategic Management Journal, 14(3), 193-213.

Schwartz, P. (1996). The art of the long view. New York, NY: Currency Doubleday.

Seybold, P. (2001). The customer revolution. New York, NY: Crown Business.

Spears, L. C. (2010). Character and servant leadership: Ten characteristics of effective, caring leaders. The Journal of Virtues \& Leadership, 1(1), 25-30.

Stalk, G. (2004). Playing hardball: Why strategies still matter. Ivey Business Journal, 69, 2-8.

Sull, D., Holmes, R., \& Sull, C. (2015). Why strategy execution unravels—and what to do about it. Harvard Business Review, 93(3), 58-66.

Sutherland, J. W. (1975). Systems: analysis, administration, and architecture. New York, NY: Van Nostrand.

Teece, D. J. (2010). Business models, business strategy and innovation. Long Range Planning, 43(2-3), 172-194.

Teece, D. J., Pisano, G., \& Shuen, A. (1997). Dynamic capabilities and strategic management. Strategic Management Journal, 18(7), 509-533.

Thompson Jnr, A. A., Strickland 11l, A. J., \& Gamble, J. E. (2010). Crafting and executing strategy: The quest for competitive advantage (16th ed.). Berkshire, UK: McGraw-Hill.

Tilles, S. (1963). How to evaluate corporate strategy. Harvard Business Review, 41(4), 111-121.

Titus, V. K., Covin, J. G., \& Slevin, D. P. (2011). Aligning strategic processes in pursuit of firm growth. Journal of Business Research, 64(5), 446-453.

Torraco, R. J. (1997). Theory-building research methods. In R. A. Swanson and E. F. Holton (Eds.), Human resources development: Research handbook (pp. 114-137). San Francisco: Berrerr-Koehler. 
Treacy, M., \& Wiersema, F. (1993). Customer intimacy and other value disciplines. Harvard Business Review, 71(1), 84-94.

Uhl-Bien, M. (2006). Relational leadership theory: exploring the social processes of leadership and organizing. Leadership Quarterly, 17(6), 654-676.

Ungerer, G. D. (2015). A competitive strategy framework for e-business start-ups (Unpublished Ph.D. dissertation, Department of Industrial Engineering, University of Stellenbosch, Stellenbosch).

Ungerer, M. (2013). A comparative analysis on strategy disclosure reporting trends in South Africa. Southern African Business Review, December, 17(3), 27-56.

Ungerer, M. (2016). Virtuous leadership. In T. H. Veldman and A. Johnson (Eds.), Leadership_Perspectives from the coal face. Johannesburg: Knowres.

Ungerer, M., \& Vorster, S. (2015). Strategy disclosure reporting trends in South Africa: A 2010-2011 comparative analysis for six industry clusters. Southern African Business Review, 19(3), 78-101.

Ungerer, M., Herholdt, J., \& Le Roux, J. (2013). Leadership for all-Virtue practices to flourish. Johannesburg: Knowledge Resources.

Ungerer, M., Pretorius, M., \& Herholdt, J. (2011). Viable business strategies: A fieldbook for leaders (3rd ed.). Randburg: Knowres Publishing.

Ungerer, M., Ungerer, G., \& Herholdt, J. (2016a). Crystallising the strategic business landscape: Strategy analysis practices and tools for business leaders and strategy practitioners. Randburg: Knowres Publishing.

Ungerer, M., Ungerer, G., \& Herholdt, J. (2016b). Navigating strategic possibilities: Strategy formulation and execution practices to flourish. Randburg: Knowres Publishing.

United Nations (UN). (2015a). Sustainable development goals. Retrieved on February 2, 2017 from http://www.un.org/sustainabledevelopment/news/communications-material

United Nations (UN). (2015b). Global compact. Retrieved on February $2, \quad 2017 \quad$ from https://www.unglobalcompact.org/about/government-recognition

Upton, D. M., \& Creese, S. (2014). The danger from within. Harvard Business Review, 92(9), 94-101.

Van der Heijden, K. (2001). Back to basics: Exploring the business idea. Strategy \& Leadership, 29(3), 13-18.

Van Praag, M. C., \& Versloot, P. H. (2007). What is the value of entrepreneurship? A review of recent research. Small Business Economics, 29(4), 351-382.

Varum, C. A., \& Melo, C. (2010). Directions in scenario planning literature: A review of the past decades. Futures, 42(4), 355-369.

Volberda, H. W., Morgan, R. E., Reinmoeler, P., Hitt, M. A., Ireland, R. D., \& Hoskisson, R. E. (2011). Strategic management: Competitiveness and globalisation. Andover, UK: Cengage.

Vorster, S., Ungerer, M., \& Volschenk, J. (2013). 2050 Scenarios for long-haul tourism in the evolving global climate change regime. Sustainability, 5(1), 1-51.

Wang, D., \& Hackett, R. D. (2015). Conceptualisation and measurement of virtuous leadership: Doing well by doing good. Journal of Business Ethics, February. Retrieved on November 3, 2015 from http://link.springer.com/article/10.1007\%2Fs10551-015-2560-1\#/ page-1

Weick, K. E. (1989). Theory construction as disciplined imagination. Academy of management Review, 14(4), 516-531.

Wernerfelt, B. (1984). A resource-based view of the firm. Strategic Management Journal, 5(2), 171-180.

Wheatley, M. J. (2007). Finding our way: Leadership for an uncertain time. San Francisco: Berrett-Koehler Publishers.

Whetton, D. A. (1989). What constitutes a theoretical contribution? Academy of Management Review, 14(4), 490-495.

World Economic Forum (WEF). (2018). Global risks (13th ed.). Geneva, Switzerland: World Economic Forum. Retrieved on February 2, 2018 from http://www3.weforum.org/docs/WEF_GRR18_Report.pdf

Zook, C., \& Allen, J. (2011). The great repeatable business model. Harvard Business Review, 89(11), 107-114.

Zott, C., Amit, R., \& Massa, L. (2011). The business model: Recent developments and future research. Journal of Management, 37(4), 1019-1042. 